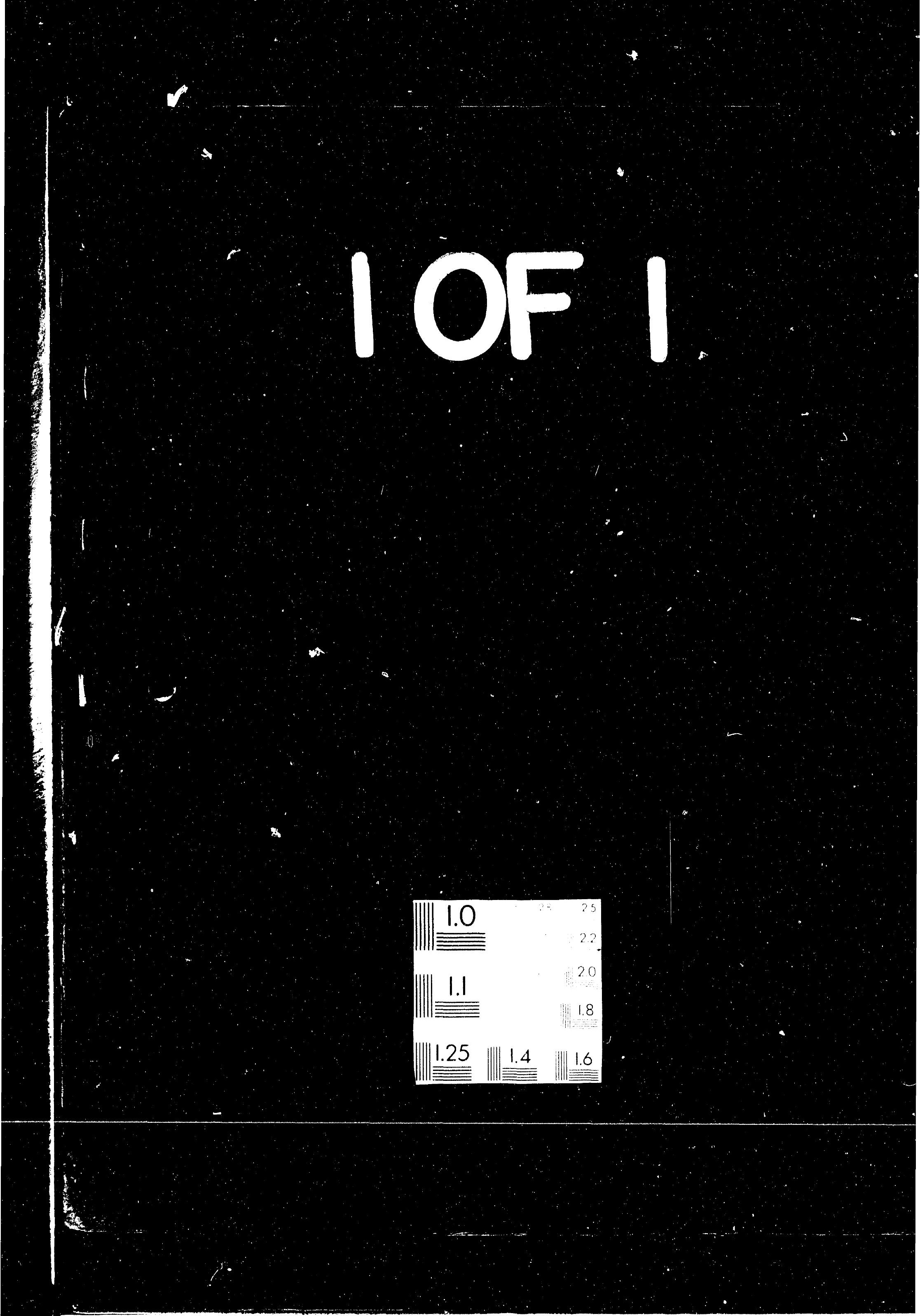


UCRL-JC-114129

PREPRINT

\title{
Chemical Kinetics and Oil Shale Process Design
}

\author{
Alan K. Burnham
}

This paper was prepared for submittal to the NATO Advanced Study Institute: Composition:

Geochemistry and Conversion of Oil Shale

\section{Akcay, Turkey}

July 18-31, 1993

July 1993
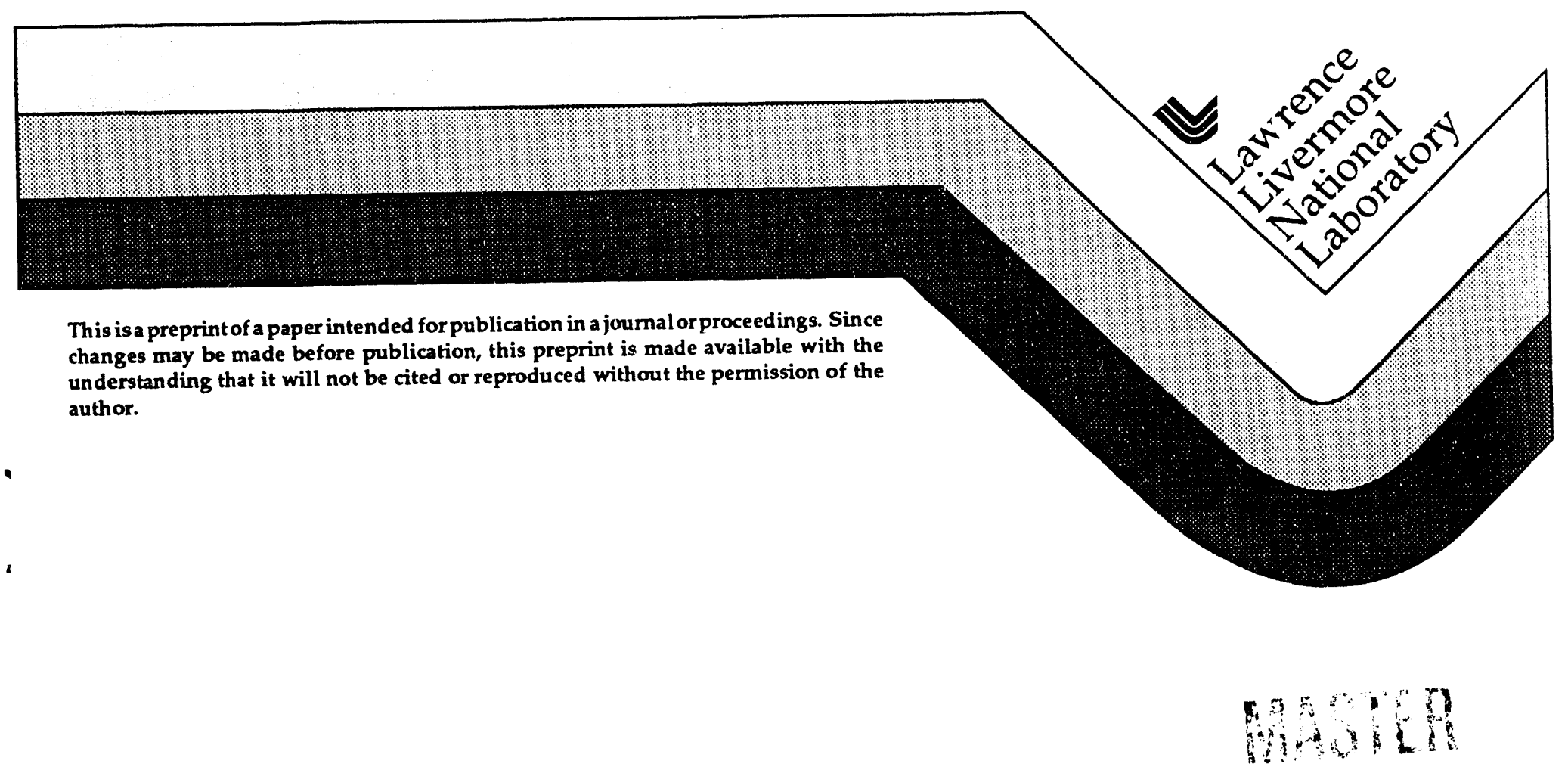


\section{DISCLAIMER}

This document was prepared as an account of work sponsored by an agency of the United States Government. Neither the United States Government nor the University of California nor any of their employees, makes any warranty, express or implied, or assumes any legal liability or responsibility for the accuracy, completeness, or usefulness of any information, apparatus, product, or process disclosed, or represents that its use would not inf ringe privately owned rights. Reference herein to any specific commercial products, process, or service by trade name, trademark, manufacturer, or otherwise, does not necessarily constitute or imply its endorsement, recommendation, or favoring by the United States Government or the University of California. The views and opinions of authors expressed herein do not necessarily state or reflect those of the Lnited States Government or the University of California, and shall not be used for advertising or product endorsement purposes. 


\title{
CHEMICAL KINETICS AND OIL SHALE PROCESS DESIGN
}

\author{
Alan K. Burnham \\ Lawrence Livermore National Laboratory \\ Livermore, CA 94551
}

\begin{abstract}
Oil shale processes are reviewed with the goal of showing how chemical kinetics influences the design and operation of different processes for different types of oil shale. Reaction kinetics are presented for organic pyrolysis, carbon combustion, carbonate decomposition, and sulfur and nitrogen reactions.
\end{abstract}

\section{Introduction}

The processing of oil shale involves numerous chemical reactions, not only those leading directly to oil and gas generation but also those required for process heat. In addition to desired products, the chemical reactions also generate by-products that can lead to environmentally undesirable emissions. An understanding of all these chemical reactions and their rates can help design processes that minimize the total processing cost, including the cost associated with meeting environmental regulations. The chemical kinetics can be incorporated, where appropriate, into mathematical models that simulate the interaction of various chemical and physical processes (e.g., Lewis and Braun, 1981; Braun et al., 1984; Cena and Thorsness, 1992).

\section{Types of Oil Shale Processes}

A first step in understanding the role of chemical reactions in process design is to outline the various kinds of processes that are used to generate shale oil. All oil shale processes require heat to generate oil. Therefore, the first step in designing a process is to decide how to generate the heat and how to transfer it to the raw shale. Many approaches have been tried (Baughman, 1978), and various authors have attempted to classify these approaches (e.g., Lewis et al., 1984; Gwyn et al., 1980).

Fundamentally, most processes can be separated into four types based on the medium used to heat the shale, i.e., those that use hot gas to heat the shale, those that use hot solids, those that use hot liquids, and those that use electromagnetic radiation. The hot-solids retorts can be further subdivided into two types according to whether the heat carrier is reactive (e.g., burned shale) or inert (ceramic balls). The hot-gas retorts can be further subdivided into two types: direct (internal combustion) and indirect (external combustion). Both the hot gas and hot liquids might also be subdivided into reactive and unreactive heat carrier types. An example of a reactive hot gas would be high-pressure hydrogen (Roberts 
et al., 1991), although combining high-pressure hydrogen with a solid heat carrier would greatly reduce gas pumping costs. Hot liquids retorting (e.g., Cha et al., 1989) might use a recycled hydrogen donor solvent to extract a bitumen (Baldwin et al., 1985). The electromagnetic types consist of radio-frequency ( $\mathrm{rf}$ ) and solar methods. Radio-frequency energy can penetrate the oil shale and deposit over lengths of meters (Bridges and Sresty, 1991). Solar methods could be classified in different ways depending how the solar energy is transferred to the shale. Hot-gas and rf methods can be used in situ.

A combustion retort and a hot-recycled-solids retort are shown in Figure 1 along with most of their important chemical reactions. The combustion retort is considered a hot-gas retort because the primary mechanism of heat transfer in the direction of the propagation of the flame front is via the gas phase. The combustion wave can either propagate down a

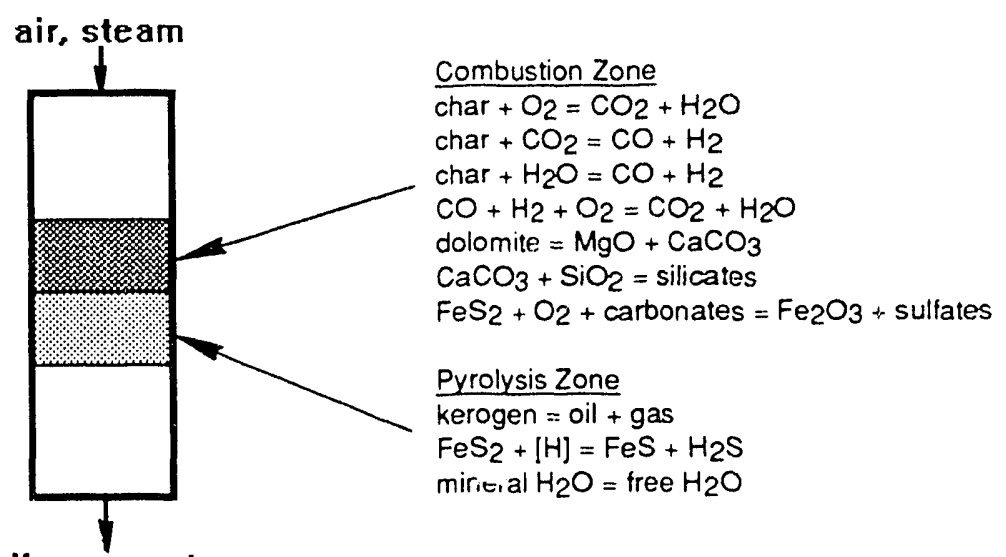

oil, gas, water

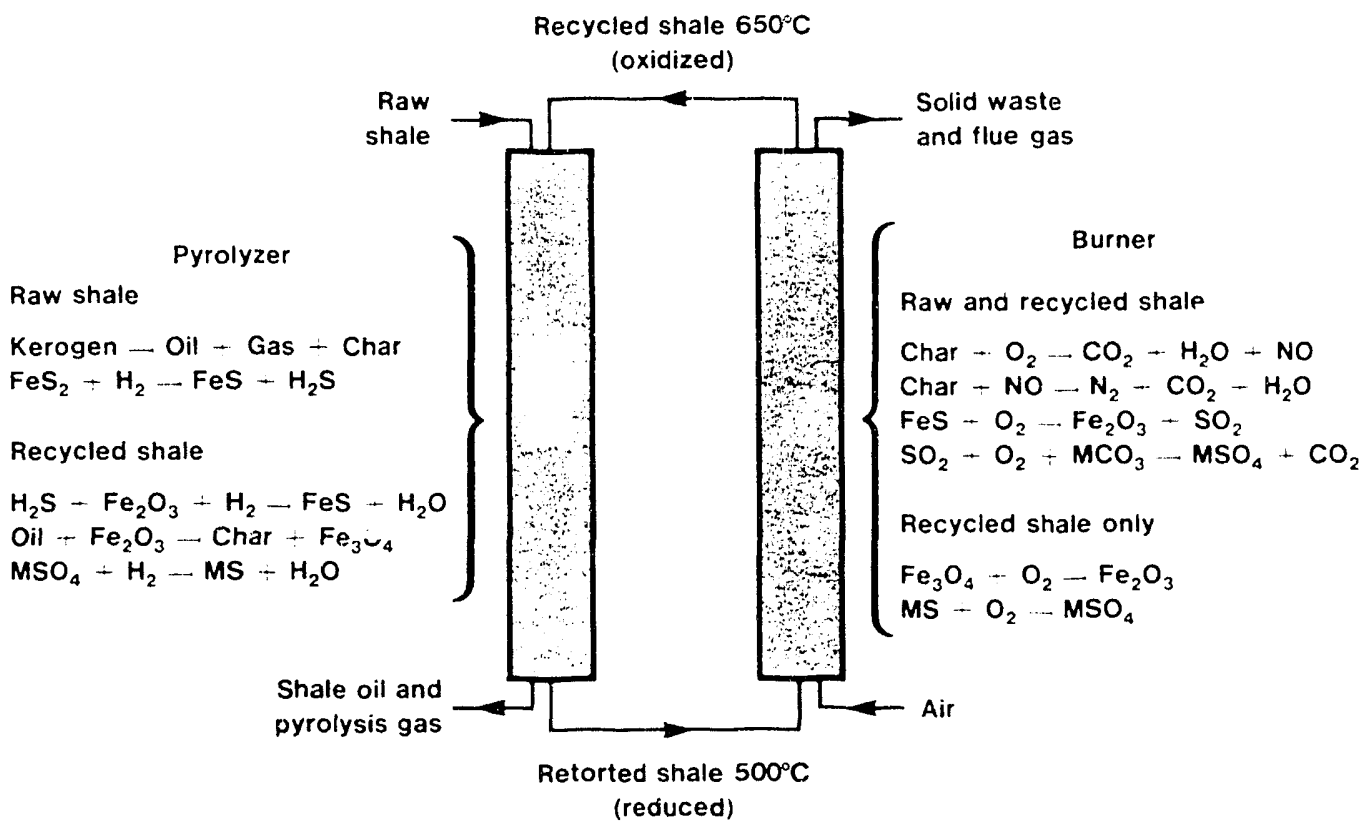

Figure 1. Combustion and hot-recycled-solids retorts with important chemical reactions. In the hot-recycled-solids reactions, $M$ represents magnesium and calcium. 
stationary bed or be maintained in a fixed position as the shale passes through the reactor vessel. In some cases, the combustion zone is stabilized by injection of part of the off-gas in the middle of the retort. A disadvantage of the combustion retort is that the off-gas is diluted by $\mathrm{N}_{2}$ and $\mathrm{CO}_{2}$. The hot-recycled-solids (HRS) retort uses iron oxide in the recycled burned shale to scrub most of the sulfur out of the pyrolysis gas, thereby producing a high-quality fuel gas in addition to the shale oil. For carbonate-containing shales, the dilute phase combustion and short residence times allow the residual carbon fuel to be burned with minimum carbonate decomposition, even though the carbonates still effectively scrub the $\mathrm{SO}_{2}$ produced irom iron sulfide oxidation.

An important design aspect is heat transfer. Within this topic, there are two issues: the heat capacity of the heat carrier, and the time it takes to transfer the heat from the carrier uniformly through the raw shale.

For either hot-solids or indirect hot-gas retorts, roughly the same mass of heat carrier must contact the r.w shale. The exact ratio depends on the entering temperatures of the raw shale and heat carrier and whether the flow is co-current (same exit temperature) or counter-current (outgoing heat carrier reaches the temperature of incoming shale for more cumplete heat exchange). Hot-gas retorts are easier to conceive as counter-current, but a counter-current hot-solids retort could be designed based on differences in particle sizes flowing in opposite directions in a fluidized bed (Gwyn et al., 1980). For hot-gas retorts, since the density of gas is about 1000 times less than shale, a large volume of gas must be pumped through the shale to heat it. This requires a design that balances shale particle size and gas flow rates to make sure that fluidization occurs only where desired.

The time required to transfer the heat from the carrier to the shale depends crucially on particle size, because of both the surface-to-volume ratio and the time needed to conduct the heat to the interior of the particle. The heatup time scales roughly as diameter squared for large particles $(>1 \mathrm{~cm})$. Approximate heatup times are $2.5 \mathrm{~min}$ for $1 \mathrm{~cm}, 4 \mathrm{~h}$ for $10 \mathrm{~cm}$, and 17 days for $1 \mathrm{~m}$. Breaking rock into small pieces costs money, so one does not want to create any smaller particles than required. However, reactor volumes and process costs increase with processing time, so one needs to reduce the shale to particles sufficiently small for effective processing. In reality, it is impossible to reduce particle size uniformly, so an optimized industry could conceivably involve several processes using different sized shale. Radio-frequency methods avoid traditional heat transfer issues. Instead, the heat is deposited according to the electric field density, enabling one to deposit energy more uniformly in large particles (Bridges and Sresty, 1991). However, the greater cost of if energy relative to thermal energy is a disadvantage.

\section{Chemical Reaction Rates in Oil Shale Processing}

\section{3.i. HYDROCARBON GENERATION AND CRACKING}

The most important reaction in oil shale processing is that leading to shale oil. It is possible to develop global rate constants for this reaction that predict the timing of oil generation at virtually all time scales, including rapid fluid-bed retorting, slow in-situ retorting, and even natural petroleurn formation. These rate constants can help determine processing times and, consequently, reactor volumes, since reactor volume depends on throughput times the processing time. Rate constants have also been developed for 
secondary reactions that affect both oil quality and quantity. The pyrolysis reactions generate gas as well as oil. The composition of the gas depends on the processing time and the way the shale is heated

An examination of the extensive literature leads to an incredible diversity of kinetic models (reaction networks and rate expressions) for conversion of kerogen to oil and gas. To establish some sense of order, it is useful to establish two guidelines: (1) any activation energy less than $170 \mathrm{~kJ} / \mathrm{mol}(40 \mathrm{kcal} / \mathrm{mol})$ is probably not a valid measure of intrinsic chemical kinetics, and (2) bitumen generation is faster than oil generation by about $25^{\circ} \mathrm{C}$ at all temperatures, requiring that the mean activation energies cannot be more than a few $\mathrm{kcal} / \mathrm{mol}$ different. A partial justification of these conclusions is given in a separate paper in this volume (Burnham, 1993).

As a reference, consider the time scale for hydrocarbon generation from a type I oil shale (Green River Formation) and a generic type II oil shale using kinetics that are reasonable at both laboratory and geological heating rates (type I: $A=5 \times 10^{13} \mathrm{~s}^{-1}$ and 7,90 , and $3 \%$ of the potential at 49,53 , and $54 \mathrm{kcal} / \mathrm{mol}$, respectively; type II: $A=3 \times 10^{13} \mathrm{~s}^{-1}$ and $5,15,45,20,10$, and $5 \%$ of the potential at $49-54 \mathrm{kcal} / \mathrm{mol}$, respectively). Type I oil shales (50-80\% conversion of kerogen to oil) are usually lacustrine and type II oil shales (30-50\% conversion to oil) are usually marine. The generation curves for several heating rates of potential interest are shown in Figure 2. The time to complete retorting for the four heating rates are 8 years, 8 days, $50 \mathrm{~min}$, and $2 \mathrm{~min}$. When compared to the heatup times mentioned in the preceding section, it is evident that rapid oil-shale processing (retorting in a few minutes) is limited to particles no greater than a centimeter or so. Slow aboveground processing (retorting within an hour or so) might use particle sizes several times larger. Modified in-situ processing would most likely retort particles between $10 \mathrm{~cm}$ and 1

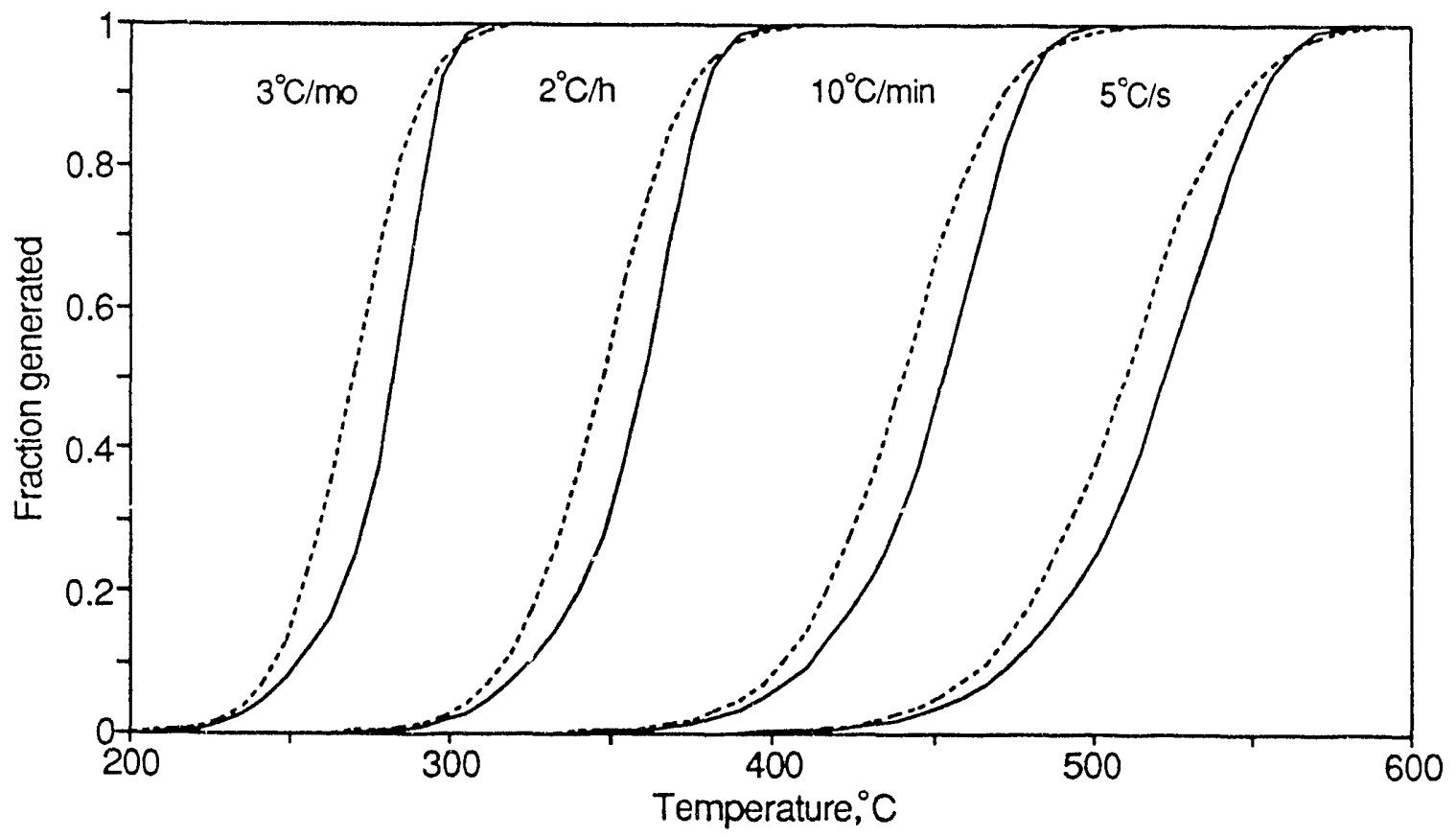

Figure 2. Hydrocarbon generation curves for type II (dashed) and type I (solid) oil shales for shale heated at constant rates ranging from $3^{\circ} \mathrm{C} / \mathrm{mo}$ to $5^{\circ} \mathrm{C} / \mathrm{s}$. 
$\mathrm{m}$, thereby requiring even longer processing iimes. These in-situ retorts involve the propagation of a combustion wave down a rubble column, giving effective heating rates at a fixed point ranging from about $1^{\circ} \mathrm{C} / \mathrm{min}$ to about $1^{\circ} \mathrm{C} / \mathrm{h}$. The slowest heating rate represents the lower limit of human-processing interest and could conceivably represent the processing of very large volumes of oil shale by if heating.

A more general understanding of the kineiics of oil generation comes primarily from organic geochemistry, both from source rock kinetic analyses and standard Rock-Eval analyses (Tissot et al., 1987; Braun et al., 1991). Type II shales generate most of their oil faster than type I oil shales (e.g., lower Rock-Eval $\mathrm{T}_{\max }$ ), although type II shales contain a broader reactivity distribution that requires about the sarne time to complete retorting. However, type II kerogen kinetics depend more strongly on natural maturation: the overall reactivity slows by about a factor of two (increase in Rock-Eval $\mathrm{T}_{\max }$ from 420 to $435^{\circ} \mathrm{C}$ ) as kerogen eliminates its oxygen during diagenesis prior to substantial generation. Type $\mathrm{I}$ kerogens ordinarily start with less oxygen in the kerogen, and the kinetics are nearly independent of natural maturation until most of the oil has been generated naturally. The kinetics of both can be accelerated by the incorporation of sulfur during early diagenesis (Tegelaar, 1993). Oil shales with well-preserved algal bodies. whether of marine or lacustrine origin, have similar kinetics and tend to have an induction time for oil generation (Bar et al., 1988; Klomp and Wright, 1990).

One special issue for oil generation kinetics from fluidized beds is that most early measuremerits of this type suffered from a large apparent tail to the generation curve. At first, it was thought that the tail was due to the generation of additional heavy oil (Wallman et al., 1981). However, more recent work (Coburn et al., 1989a) has demonstrated that most of the tail is an artifact of oil adsorption on dust in the apparatus, as shown in Figure 3. When removed, the shape of the pyrolysis curve agrees with that predicted by nonisothermal kinetics (Burnham et al., 1989). Wher the oil adsorption artifact is removed, type $\Pi$ oil shales tend to have a longer tail than type I oil shales, which is consistent with the need for an activation energy distribution to describe nonisothermal kinetics.

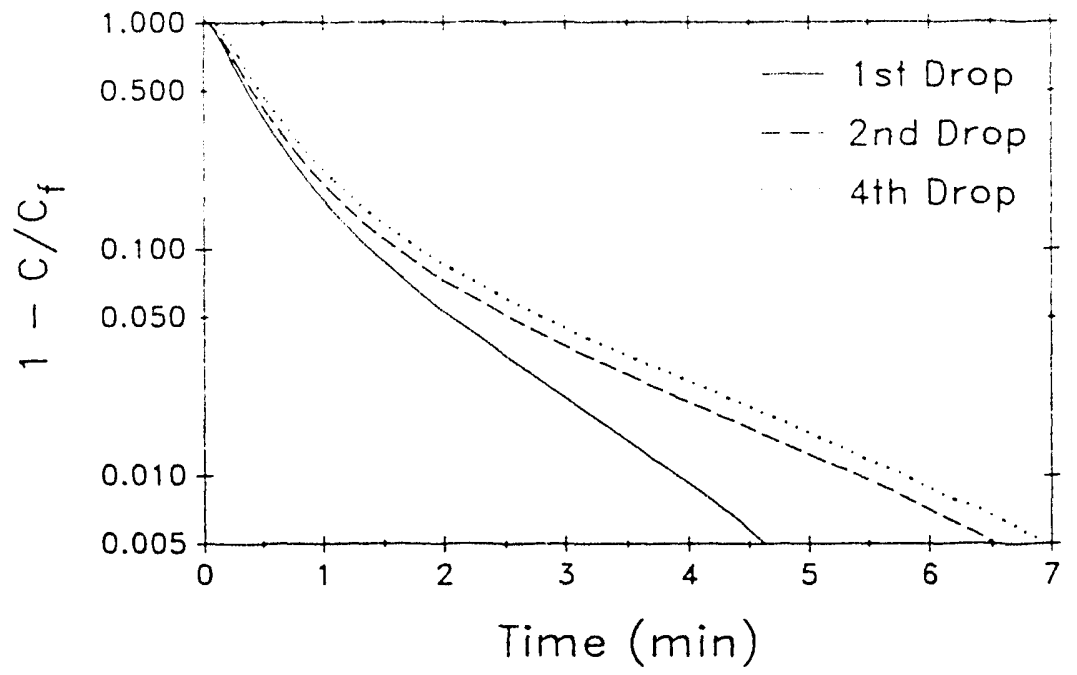

Figure 3. Logarithm of the fraction of remaining potential as a function of time for a type II oil shale (New Albany, $54 \mathrm{~L} / \mathrm{Mg}$ ). The longer tail on the successive drops is due to oil hold-up on a dust filter in the apparatus that accumulates more dust with each drop. 
There has been considerable confusion about the relative generation kinetics of oil and gas. Early nonisothermal experiments (Huss et al., 1982) suggested that gas generation from Green River kerogen peaked at a higher temperature, implying slcwer kinetics, than oil. However, later nonisothermal and :uthermal experiments have shown that most of the hydrocarbon gas from type I oil shales has the same kinetics as oil, although some of the methane is generated by a slower process (Reynolds et al., 1991). For type II oil shales, most of the hydrocarbon gas still has the same kinetics as oil, but a much larger fraction of the methane is generated by the slower process. Hydrogen generation from Green River oil shale peaks and continues to a higher temperature than hydrocarbons during nonisotherma! pyrolysis. Hydrogen also shows an induction period for isothermal pyrolysis (Richardson et al., 1982), indicating that it is formed primarily from a product of kerogen decomposition. Therefore, more complete retorting should give a higher hydrogen content in the product gas.

Oil yield depends on heating rate because of secondary reactions, as shown in the general scheme in Figure 4 (Campbell et al., 1978). Oil yield decreases with heating rate due to liquid-phase coking reactions. The coking tendency is related to the aromatic content of the oil so has a larger effect for type II shales than type I shales. The beneficial aspect of coking is that it tends to increase oil quality by increasing the $\mathrm{H} / \mathrm{C}$ ratio and decreasing ritrogen content. Pressure seems to enhance coking, at least initially, by increasing the liquid-phase residence time (Burnham and Singleton, 1983).

Oil cracking decreases oil yield by converting aliphatic material to mostly gas. Most published oil-cracking kinetics suffer from an artificially low apparent activation energy, probably because of the distribution of reactions occurring. The role of pressure on oil cracking is complicated (Mallinson et al., 1992). Ai high temperatures, pressure increases chain transfer reactions that increase the destruction of a particular molecule, but the overall conversion to gas is partially mitigated by enhanced recombination and alkylation reactions. At temperatures below about $350^{\circ} \mathrm{C}$, recombination reactions dominate, so pressure actually decreases the overall cracking rate. Oil cracking and coking are accelerated by the presence of a clean mineral surface and can be modeled by an adsorption isotherm approach (Wallman, 1991).

- Uil production

$$
\text { (Kerogen-Bitumen) } \stackrel{k_{d}}{\longrightarrow} \text { Oil }(\ell, v, g)+\text { Gas }+ \text { Char }
$$

- Oil coking

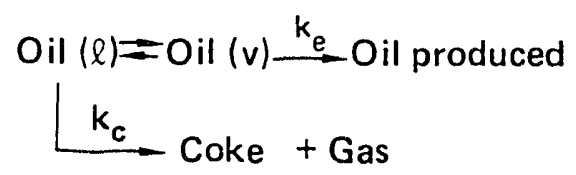

- Oil cracking

Oil $(v, g) \stackrel{k_{f}}{-}$ Gas + Coke

Figure 4. Kinetic scheme for oil generation and destruction. Coking occurs in the liquid phase producing mostly coke; Cracking occurs in the gas phase producing mostly gas. 
High-pressure hydrogen increases oil yield by providing the driving force to prevent recombination reactions by reactive fragments, and the increased yield is primarily aromatic oil (Burnham and Happe, 1984; McMahon and de Paz, 1989). The yield enhancement is especially important for type II oil shales because they tend to be more hydrogen de, icient (Roberts et al., 1991).

It has been proposed that steam has a beneficial effect on the organic reactions of oil shale retortir : (Allred, 1979). At present, it seems certain that steam decreases the pour point of the oil (Burnham, 1981) and gives a slight yield enhancement (Carter and Taulbee, 1986; Dung, 1990), possibly due the inhibition of surface-catalyzed coking reactions (Coburn et al., 1989b). However, a purported increase in oil generation rate (Allred, 1979) seems to be an artifact of the experimental apparatus because it is not observed in other experiments.

$f$. separate paper in this volume (Burnham, 1993) addresses the mechanism of oil generation and that kerogen in most oil shale breaks down initially into soluble material and then into volatile oil and gas, though not by an ideal serial reaction. Some have proposed that kerogen be extracted by thermal dissolution, thereby recovering a higher fraction of the organic matter (Patzer et al., 1986). It is often postulated that, once the organic matter is in a form that can access catalysts, a more efficient pathway to products might be achievable than via the tradicional thermal cracking. The relevant kinetic issue is the time-temperature severity required to extract the kerogen. Miknis et al. (1987) found that nearly all the kerogen from Green River shale could be recovered as oil and bitumen in 20 minutes at $425^{\circ} \mathrm{C}$. Actual kinetic parameters for bitumen generation are much less well determined than for oil generation; most published activation energies are too low for the reasons discussed earlier. The low apparent activation energies predict that kerogen is not stable on a geologic time scale, although we know that the natural generation of bitumen occurs at about $100^{\circ} \mathrm{C}$. The correct activation energies appear to be about 210 $\mathrm{kJ} / \mathrm{mol}(50 \mathrm{kcal} / \mathrm{mol})$.

\subsection{THE ROLE OF SULFUR IN PYROLYSIS}

Sulfur in the kerogen is important for two reasons: (1) it affects the overall generation rate of oil and gas, and (2) it leads to sulfur species in both the oil and gas that must be removed. Although the factors affecting the relative generation kinetics of various kerogens are not clearly understood, the evidence that organic sulfur accelerates the process is strong (Tegelaar, 1993). High-sulfur kerogens, such as in the Monterey shale, produce oil as much as $50^{\circ} \mathrm{C}$ in Rock-Eval pyrolysis lower than well-preserved, low-sulfur algal kerogens, such as the Green River oil shale. Less well understood is the effect on the activation energy. Ordinary pyrolysis giv's activation energies about $220 \mathrm{~kJ} / \mathrm{mol}$ (Tissot et al., 1987; Jarvie, 1991). Other work (Hunt et al., 1991) tends to overestimate the effect of sulfur on the activation energy due to the assumption of a single first-order reaction.

Sulfur in the oil and gas can affect upgrading and utilization costs. The sulfur content of the oil depends primarily on the sulfur content of the kerogen (Burnham, 1991). Incorporation of inorganic sulfur into the oil seems to be minor. Sulfur content of the gas depends on both kerogen and pyritic sulfur. The reactions leading to sulfur-containing gases occur slightly faster than the overall kerogen decomposition rate (Burnham and Taylor, 1982). Pyrite reacts with both water and organics during pyrolysis to produce additional sulfur-containing gases. The rate of this reaction depends on both the reactivity 
of the pyrite (primarily particle size: Hoare, 1987) and the gas-solid contact (Burnham and Taylor, 1982). About $95 \%$ of the gaseous sulfur is in the form of $\mathrm{H}_{2} \mathrm{~S}$, with most of the remainder in methanethiol, ethanethiol, and carbonyl sulfide (Wong et al., 1984a). There seems to be little difference in the relative amounts of $\mathrm{H}_{2} \mathrm{~S}$ and mercaptans formed from organic and inorganic sulfur, although inorganic sulfur does not form thiophenic compounds (Wong et al., 1984b). Some rhales contain a separate $(\mathrm{Mg}, \mathrm{Fe}) \mathrm{CO}_{3}$ phase, which decomposes readily at or below $500^{\circ} \mathrm{C}$, providing a source of iron to capture $\mathrm{H}_{2} \mathrm{~S}$ as FeS. The iron-rich surface layer of ankeritic-dolomite can also capture some sulfur. In hot-recycled solids retorts, iron oxi formed from combustion of iron sulfides is an effective capture agent. However, fate of the captured sulfur in the combustor depends on the presence or absence of carb. 2 tes, as discussed in the next section.

\subsection{HEAT SOIMCE AND SINK REAR JNS}

Although the enthalpy of the conversion of kerogen to oil and gas is fairly small, oilshale processing requires a substantial heat source because the sensible heat recovered from the products is usually far less than required to heat the raw shale to pyrolysis temperatures. Oil-shale retorting leaves a carbonaceous residue, and efficient oil-shale processes will burn this residue to provide process heat (about $380 \mathrm{~kJ} / \mathrm{kg}$ shale per wt $\%$ residual $\mathrm{C}$ ). Oxidation of sulfide minerals can lead to a substantial exothermic contribution (107-320 kJ/kg per wt\% sulfur, depending on the pyrite/pyrrhotite ratio and the degree of sulfate formation). Decomposition of carbonate minerals can be a substantial heat sink (18-28 kJ/kg per wt $\% \mathrm{CO}_{2}$, depending on the degree of silication). Gasification of char by the mineral $\mathrm{CO}_{2}$ is also endothermic, but oxidation of the resulting $\mathrm{CO}$ in the gas stream is exothermic. The sulfide, carbonate, and gasification reactions are affected by steam. Carbonate minerals also play a key role in reducing sulfur dioxide in the flue gas.

The reactivity of the pyrolysis residue (char) to oxygen and other gases depends on its generation history, with rapid pyrclysis leading to more a more reactive char (Fujumoto et al., 1987; Thorsness et al., 199?). The reason for the heating rate dependence is not known. The limited information on surface area suggests that the surface areas are not substantially different. The residues from Green River shale at all heating rates are far more reactive than typical coals, probably because of the higher hydrogen content. There are two practical implications of this high reactivity: (1) the oxidation reactions are diffusion-limited except for small particles at relatively low temperatures (Aldis et al., 1992), and (2) the residence time in the combustion zone does not have to be very long for hot recycled shale retorts using fine particles. For the small particles associated with the HRS process, most of the fuel value of the char can be extracted in le: than one minute residence time at $530^{\circ} \mathrm{C}$, and substantially less at a more typical combustor temperature of $700^{\circ} \mathrm{C}$ (Cena and Thorsness, 1992). In contrast, diffusion limitations cause combustion times of 1-2 days at comparable temperature for the $15-\mathrm{cm}$ particle sizes typical of modified in-situ retorts (Mallon and Braun, 1976).

The carbonate decomposition reactions, for those shales that have carbonate, depend on gas atmosphere, as shown in Figure 5 (Campbell, 1978; Burnham et al., 1980). Decomposition of dolomite is only weakly and indirectly affected by $\mathrm{CO}_{2}$; the primary difference is in whether $\mathrm{CaO}$ or $\mathrm{CaCO}_{3}$ is formed. Calcite decomposition is frequently inhibited because of its low equilibrium vapor pressure. In a flue gas containing $15 \% \mathrm{CO}_{2}$, the calcite cannot decompose to $\mathrm{CaO}$ unless $\mathrm{T}$ is greater than about $800^{\circ} \mathrm{C}$, although it does 


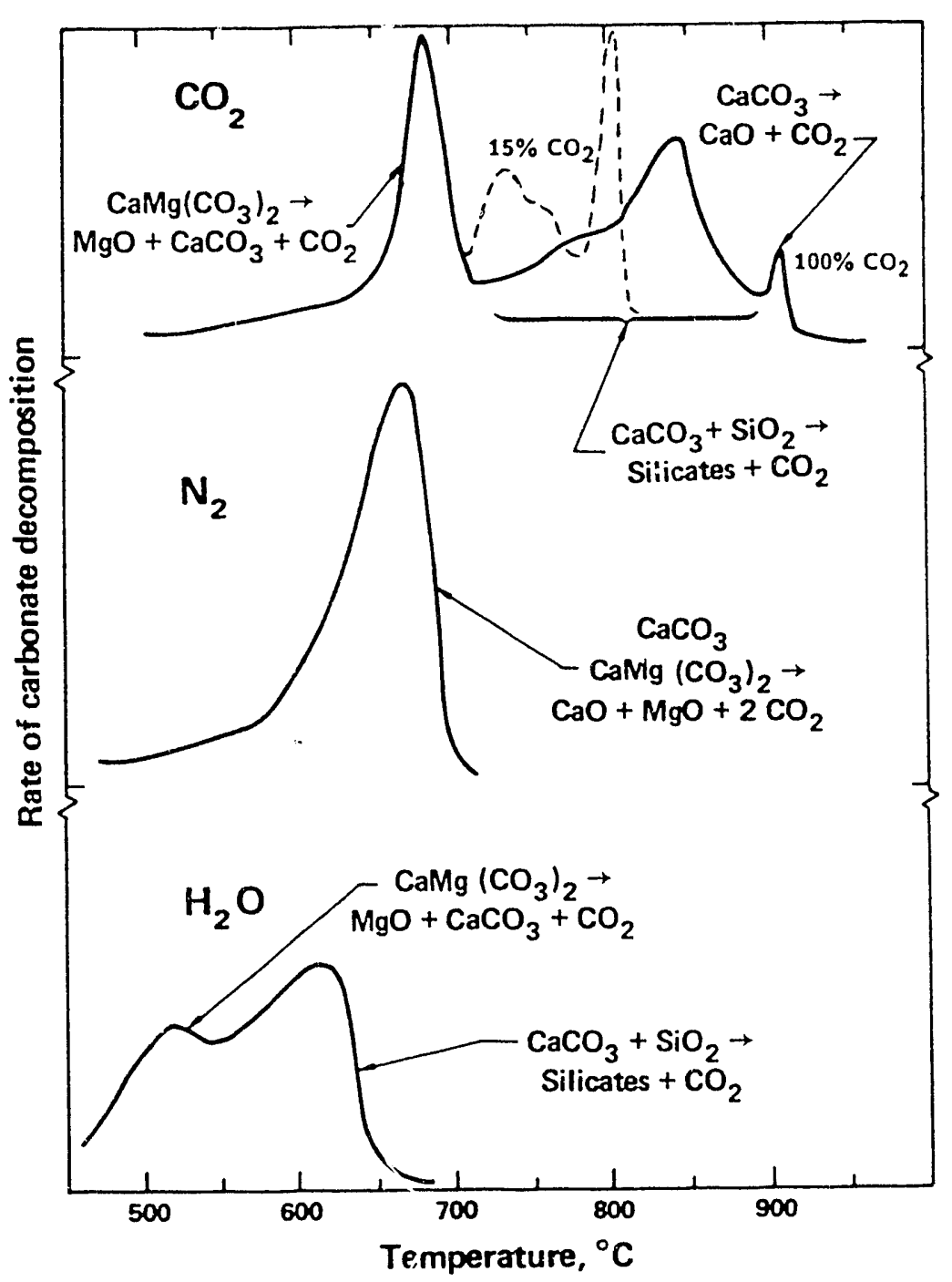

Figure 5. Thermal decomposition profiles of carbonate minerals in Green River shale heat at $2^{\circ} \mathrm{C} / \mathrm{min}$ in various gas atmospheres.

react directly at lower temperatures with quartz and other silicates. Most of the iron contained in carbonates in Green River shale is ordinarily contained in the dolomite, often in an iron-rich surface layer (Coburn et al., 1989) that decomposes slightly faster than the bulk.

The sulfur captured during pyrolysis either by iron carbonates or recycled iron oxides, when returned to the combustor in a HRS process, provides additional heat to the process. The kinetics of capture are favorable for both Green River and New Albany shale, but the net heat gain is slightly different for the two cases because about $30 \%$ more energy can be obtained forming sulfates from carbonates than by forming $\mathrm{SO}_{2}$ in the absence of carbonates (Burnham and Taylor, 1982). 
The overall energy released during combustion depends on spent shale composition and the final products. Char and pyrite are the major energy sources, and carbonate, if present, is the major heat sink when the temperature is high enough to decompose it. The fraction of kerogen carbon remaining in the shale correlates with both the $\mathrm{H} / \mathrm{C}$ ratio of the kerogen and pyrolysis conditions. Most marine shales, such as the Eastern U.S. Devonian shales, leave a much higher fraction of their carbon as char.

The amount of heat required for the process depends largely on the exit temperature of the products. About $700 \mathrm{~kJ} / \mathrm{kg}$ of heat is required for products of Green River shale exiting at $500^{\circ} \mathrm{C}$ (Camp, 1987; Burnham, 1989). The heat requirement increases from 600 to 800 $\mathrm{kJ} / \mathrm{kg}$ over the range of 20 to $200 \mathrm{~L} / \mathrm{Mg}$, and the distribution of sensible heat between volatile and solid products and the contribution of heats of reaction vary. The spent shale organic carbon is roughly equal to 0.028 times the oil yield in $\mathrm{L} / \mathrm{Mg}$, so the retorting process would be energy self-sufficient at $65 \mathrm{~L} / \mathrm{Mg}$ for no pyrite oxidation or carbonate decomposition. A higher grade would be needed to sustain the process if the shale in an HRS process leaves the recycle loop at the peak combustion temperature, as discussed in the next paragraph. Type II shales have a much higher coke/oil ratio, so they would be energy self-sufficient at lower oil grades than type I shales.

The excess energy in the char of shale grades that would be exploited first might be used to generate electricity. Such a scheme markedly increases the economics of processing Green River Formation oil shale (Wallman, 1992), where the flue gas is self-scrubbed by the carbonate minerals. For Eastern U.S. Devonian oil shales, there is more carbon available, but this advantage is counter-balanced by the lack of carbonates to scrub $\mathrm{SO}_{2}$. The Kentort II process (Carter and Taulbee, 1990) adds a gasification reactor section to maximize the recovery of the fuel value as a reduced gas, thereby allowing removal of the sulfur as $\mathrm{H}_{2} \mathrm{~S}$ rather than as a more difficult, dilute $\mathrm{SO}_{2}$ in the flue gas. The economic value of the $\mathrm{H}_{2} \mathrm{~S}$ is then recovered as elemental sulfur rather than electricity. The gasification also removes a potential source of acid drainage from the disposed spent shale.

Counter-current combustion retorts (e.g., Paraho direct) have the advantage that the inlet air can cool the shale to about $200^{\circ} \mathrm{C}$, thereby potentially reducing the heat required by about $200 \mathrm{~kJ} / \mathrm{kg}$, eci.ivalent to the fuel value of $0.5 \mathrm{wt} \% \mathrm{C}$. In practice, however, counter-current retorts require large enough particles that carbon accessibility is severely limited by diffusion, thereby cancelling any beneficial effect of heat exchange.

Furthermore, the increased time and temperature required to access the carbon causes more carbonate decomposition for dolomite-containing oil shales, thereby cancelling most of the energy gain.

\subsection{COMBUSTION EMISSIONS}

Environmental considerations will undoubtedly limit $\mathrm{SO}_{2}$ and $\mathrm{NO}_{\mathrm{x}}$ emissions: no more than $0.001 \mathrm{~kg} \mathrm{SO}_{2} / \mathrm{kg}$ oil and $2.5 \times 10^{-7} \mathrm{~kg} \mathrm{NO}_{\mathrm{x}} / \mathrm{kJ}$ of combustion energy in Colorado. Fortunately, there are favorable reactions in some oil shales that minimize emissions.

The high $\mathrm{Ca} / \mathrm{S}$ ratio in Green River shale makes sulfur capture very thorough at high temperatures; the important question for kinetics is whether the $\mathrm{SO}_{2}$ can be captured at the relatively low combustion temperatures desired to minimize carbonate decomposition. The capture reactions are quite effective for temperatures greater than $530^{\circ} \mathrm{C}$. Release of $<0.1 \%$ of the sulfur is easily achieved, which corresponds to $<10^{-4} \mathrm{~kg} \mathrm{SO}_{2} / \mathrm{kg}$ oil for a 
shale containing $1 \mathrm{wt} \% \mathrm{~S}$ and yielding $15 \mathrm{wt} \%$ oil. Ca-Mg sulfates are formed below $650^{\circ} \mathrm{C}$, apparently by a direct reaction of the $\mathrm{SO}_{2}$ with the dolomite, and Ca sulfate is formed at higher temperatures (Burnham and Taylor, 1982). However, shales with above average sulfur content would need higher temperatures because of the inhibition of a surface sulfate layer on the capturing carbonate at low temperature (Taylor et al., 1989).

The combustion reactions also lead to $\mathrm{NO}_{\mathrm{x}}$ through oxidation of fuel nitrogen and mineral nitrogen. The relative amounts of each depend on the shale. The resulting $\mathrm{NO}_{\mathrm{x}}$ levels are strongly affected by secondary reactions with the carbonaceous residue, inorganic components, and co-generated ammonia. Early work found that (1) retorted shale was an effective reductant of ' ' $\mathrm{O}_{\mathrm{x}}$ (Taylor and Morris, 1984), (2) most of the $\mathrm{NO}_{\mathrm{x}}$ was formed after most of the carbon was burned (Taylor et al., 1985), and (3) the mineral ritrogen source, buddingtonite, burned slower than the char (Taylor et al., 1985). This led to the hypothesis that the char limited the survival of $\mathrm{NO}_{\mathrm{x}}$ until the char was gone, then oxidation of mineral nitrogen could result in NOx. The kinetic model shown in Figure 6 reproduced the experimental results. More recently it has been found that oxidized shale under the correct conditions can serve as a de-NO $\mathrm{Na}_{x}$ catalyst (Reynolds et al., 1992), and work is in progress to use that property to minimize $\mathrm{NO}_{\mathrm{x}}$ emissions from Green River oil shale.

\section{Reactions:}

$$
\begin{aligned}
& \text { char } \rightarrow \mathrm{CO}_{2} \text { by } \mathrm{k}_{1} \\
& \text { Inorganic } \mathrm{N} \rightarrow \mathrm{NO} \text { by } \mathrm{k}_{2} \\
& \mathrm{NO} \rightarrow \mathrm{N}_{2} \text { by } \mathrm{k}_{3}
\end{aligned}
$$

$$
N O_{x}(t)=\frac{k_{2} N_{0} \exp \left(-k_{2} t\right)}{1+k_{3} \tau C_{0} \exp \left(-k_{1} t\right)}
$$

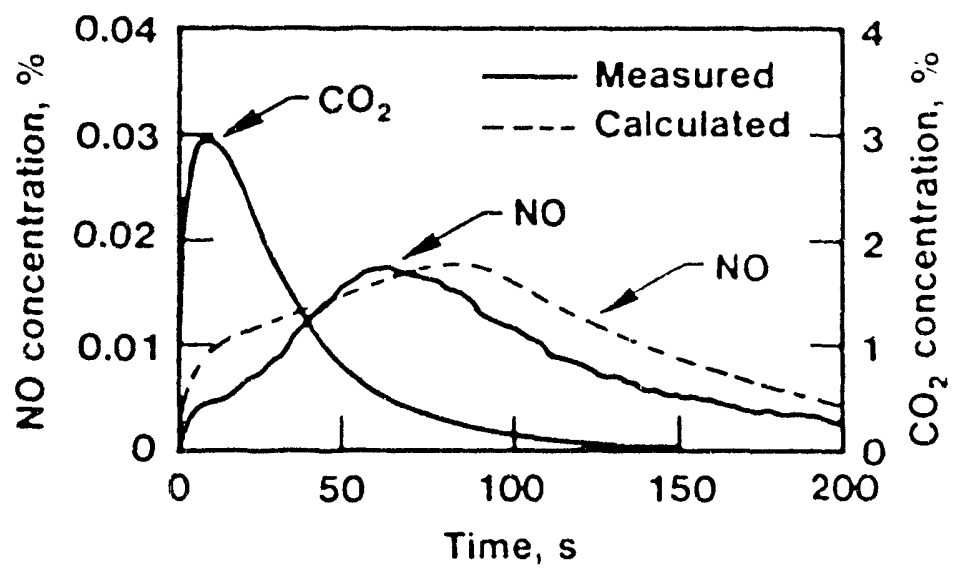

Figure 6. $\mathrm{CO}_{2}$ and $\mathrm{NO}$ release from Green River $\mathrm{Fc}$.nation oil shale during combustion at $540^{\circ} \mathrm{C}$ in a bed of sand fluidized with $10 \% \mathrm{O}_{2}$. The model assumes that $\mathrm{NO}$ is formed from inorganic nitrogen and destroyed by reaction with char, where $\tau$ is a contact time. 


\subsection{CONCLUDING REMARKS}

There are many ways to design an oil shale retort, and advances in the understandirg of oil shale chemistry has aided the conceptual development of new oil shale processes. Hotrecycled-solids processes can achieve high yield while processing the shale completely in less than 5 minutes with minimal environmental impact. Prospects are excellent for producing a nonhazardous spent shale while minimizing air emissions. Furthermore, the overall thermal efficiency (energy in shale oil and net electricity produced per energy content of raw shale plus input from mining, transportation and capital equipment) of an HRS plant co-generating of electricity (Wallman, 1991) exceeds earlier processes (Gwyn et al., 1980). Including estimates for the energy value of fuel, explosives, and capital goods according to the estimates of Gwyn et al., thermal efficiencies are estimated at $75-80 \%$ for oil yizlds of $90-100 \%$ of Fischer assay from $125 \mathrm{~L} / \mathrm{Mg}(0.8 \mathrm{bbl} /$ tonne $)$ oil shale. Ironically, it was questioned in a congressional debate during the writing of this article that it may not be possible to recover shale oil with a net energy gain. A subsequent vote may have ended U.S. oil shale research for the foreseeable future, leading it to yet another nadir.

Acknowledgements. This work was performed under the auspices of the U.S. Department of Energy by the Lawrence Livermore National Laboratory under contract W-7405-Eng48.

\section{References}

Aldis, D. F., Singleton, M. F., Watkins, B. E., Thorsness, C. B., and Cena, R. J. (1992) 2.5th Oil Shale Symp. Proc., J. H. Gary, ed., Colo. School of Mines Press, Golden, CO, pp. 71-93.

Allred, V. D. (1979) 12th Oil Shale Symp. Proc., J. H. Gary, ed., Colo. School of Mines Press, Golden, CO, p. 241.

Bar, H., Ikan, R., and Aizenshtat, Z. (1988) J. Anal. Appl. Pyr. 14, 73-79.

Baldwin, R. M., Lane, G. S., and Chen, K. W. (1985) 18th Oil Shale Symp. Proc., J. H. Gary, ed., Colo. School of Mines Press, Golden, CO, pp. 176-181.

Baughman, G. L. (1978) Synthetic Fuels Handbook, 2nd Ed., Cameron Engineers, Denver, CO.

Braun, R. L., Diaz, J. C., and Lewis, A. E. (1984) Soc. Petrol. Eng. J. 23, 75.

Braun, R. L., Burnham, A. K., and Reynoiis, J. G., and Clarkson, J. E. (1992) Energy \& Fuels 5, 192-204.

Bridges, J. E., and Sresty, G. C. (1991) 24th Oil Shale Symp. Proc., Quart. Colo. School of Mines 83, 3? -43 .

Burnham, A. K. (1981) unpublished results.

Burnham, A. K. (1989) Energy 14, 667-674.

Burnham, A. K. (1991) Energy \& Fuels 5, 205-214. 
Burnham, A. K. (1993) this volume

Burnham, A. K., Stubblefield, C. T., and Campbell, J. H. (1980) Fuel 59, 871-877.

Burnham, A. K., and Taylor, R. W. (1982) 15th Oil Shale Symp. Proc., J. H. Gary, ed., Colo. School of Mines Press, Golden, CO, pp. 299-319.

Burnham, A. K., and Happe, J. H. (1984) Fuel 63, 1352-1356.

Burnham, A. K., and Singleton, M. F. (1983) in Geochemistry and Chemistry of Oil Shales, ACS Symp. Ser. 230, F. P. Miknis and J. F. McKay, eds., American Chemical Society, Washington, pp. 335-351.

Burnham, A. K., Braun, R. L., Taylor, R. W. and Coburn, T. T. (1989) Preprints ACS Div. Petrol. Chem. 34(1), 36-42.

Camp, D. W. (1987) 2Oth Oil Shale Symp. Proc., J. H. Gary, ed., Colo. School of Mines Press, Golden, CO, pp. 187-214.

Campbell, J. H., Koskinas, G. H., Stout, N. D., and Cobur, T. T. (1978) In Situ 2, 1-47.

Campbell, J. H. (1978) The Kinetics of Decomposition of Colorado Oil Shale. II.

Carbonate Minerals, Lawrence Livermore National Laboratory Report UCRL-52089-2.

Carter, S. D. and Taulbee, D. N. (1986) Fuel Proc. Technol. 251-72.

Carter, S. D. and Taulbee, D. N. (1990) 1989 Eastern Oil Shale Proc., D. J. Lazar, ed., Institute for Mining and Minerals Research, Lexington, KY, pp. 511-518.

Cena, R. J., and Thorsness, C. B. (1992) 25th Oil Shale Symp. Proc., J. H. Gary, ed., Colo. School of Mines Press, Golden, CO, pp. 187-214.

Cha, C. Y., Guffey, F. D., and Fahy, L. J. (1989) 1988 Eastern Oil Shale Proc., D. J. Lazar, ed., Institute for Mining and Minerals Research, Lexington, KY, pp. 301-311.

Coburn, T. T., Taylor, R. W., and Morris, C. J. (1989a) 1988 Eastern Oil Shale Proc., J. Stivers, ed., Institute for Mining and Minerals Research, Lexington, KY, pp. 325-332.

Coburn, T. T., Taylor, R. W., and Morris, C. J. (1989b) 22nd Oil Shale Symp. Proc., J. H. Gary, ed., Colo. School of Mines Press, Golden, CO, pp. 118-126.

Coburn, T. T., and Morris, C. J. (1991) 1990 Eastern Oil Shale Proc., J. Stivers, ed., Institute for Mining and Minerals Research, Lexington, KY, pp. 2:9-297.

Dung, N. V. (1990) Fuel 69, 497-501.

Fujumoto, R. D., Braun, R. L., Taylor, R. W., and Morris, C. J. (1987) Energy \& Fuels 1, 320-323.

Gwyn, J. E., Roberts, S. C., Hinds, G. P. Jr, Hardesty, D. E., and Johnson, G. L., 13th Oil Shale Symp. Proc., J. H. Gary, ed., Colo. School of Mines Press, Golden, CO, pp. 35-45.

Hoare, I. C. (1987) Proc. 4th Australian Workshop on Oil Shale, pp. 113-120.

Hunt, J. M., Lewan, M.D., and Hennet, J.-C. (1991) AAPG Bulletin 75, 795-807.

Huss, E. B., and Burnham, A. K. (1982) Fuel 61, 1188-1196.

Jarvie, D. M. (1991) Chem. Geol. 93, 79-99.

Klomp, U. C. and Wright, P. A. (1990) Org. Geochem. 16, 49-60. 
Lewis, A. E., and Braun, R. L. (1981) J. Energy 5, 355-361.

Lewis, A. E., Braun, R. L., and Diaz, J. C. (1984) 17th Oil Shale Symp. Proc., J. H. Gary, ed., Colo. School of Mines Press, Golden, CO, pp. 1-16.

Mallon, R. G., and Braun, R. L. (1976) Quart. Colo. School of Mines 71(4), 309-333.

Maltinson, R. G., Braun, R. L., Westbrook, C. K., and Burnham, A. K. (1992) I\&EC Res. 31, 37-45.

McMahon, M. A., and de Paz, E. F. (1989) 22nd Oil Shale Symp. Proc., J. H. Gary, ed., Colo. School of Mines Press, Golden, CO, pp. 127-137.

Miknis, F. P., Turner, T. F., Berdan, G. L., and Conn, P. J. (1987) Energy \& Fuels 1, 477 483.

Patzer J. F., Moon, W. G., Jones, G. L., and King, A. B. (1986) Chem Eng. Sci. 41, 10051011.

Reynolds, J. G., Taylor, R. W., and Morris, C. J. (1992) Prepr. ACS Fuel Chem. Div. 37(4), 1840-1846.

Reynolds, J. G., Crawford, R. W., and Burnham, A. K. (1991) Energy \& Fuels 5, 507-523.

Richardson, J. H., Huss, E. B., Ott, L. L., Clarkson, J. E., Bishop, M. E., Taylor, J. R., and Morris, C. J. (1982) Lawrence Livermore National Laboratory Report UCID-19548.

Roberts, M. J., Rue, D. M., and Lau, F. S. (1991) 1990 Eastern Oil Shale Proc., J. Stivers, ed., Institute for Mining and Minerals Research, Lexington, KY, pp. 323-341.

Taylor, R. W., and Morris, C. J. (1984) Prep. ACS Div. Petr. Chem. 29(1), 277-283.

Taylor, R. W., Morris, C. J., and Burnham, A. K. (1985) 18th Oil Shale Symp. Proc., J. H. Gary, ed., Colo. School of Mines Press, Golden, CO, pp. 278-290.

Taylor, R. W., Morris, C. J., and Coburn, T. (1989) 1988 Eastern Oil Shale Proc., D. J. Lazar, ed., Institute for Mining and Minerals Research, Lexington, KY, pp. 147-161.

Tegelaar, E. W. (1993) unpublished results.

Tissot, B. P., Pelet, R., and Ungerer, P. (1987) AAPG Bulletin 71, 1445-1466.

Thorsness, C. B., Watkins, B. E., Aldis, D. F., and Morris, C. J. (1992) 25th Oil Shale Symp. Proc., J. H. Gary, ed., Colo. School of Mines Press, Golden, CO, pp. 55-70.

Wallman, P. H., Tamm, P. W. and Spars, B. G. (1981) in Oil Shale, Tar Sands, and Relo:ed Materials, ACS Symp. Ser. 163, H. C. Stauffer, ed., American Chemical Society, Washington, pp. 93-113.

Waliman, P. H. (1992) Energy 17, 313-319.

Wallman, P. H., Fields, D. B., Morris, C. J., Singleton, M. F., Thorsness, C. B., and Watkins, B. E., (1991) Lawrence Livermore National Laboratory Report UCRL-JC108770 , presented at the 6 th Australian Workshop on Oil Shale.

Wong, C. M., Crawford, R. W., and Burnham, A. K. (1984a) Anal. Chem. 56, 390-395.

Wong, C. M., Crawford, R. W., and Burnham, A. K. (1984b) Prepr. ACS Fuel Div., 29(3), 317-321. 

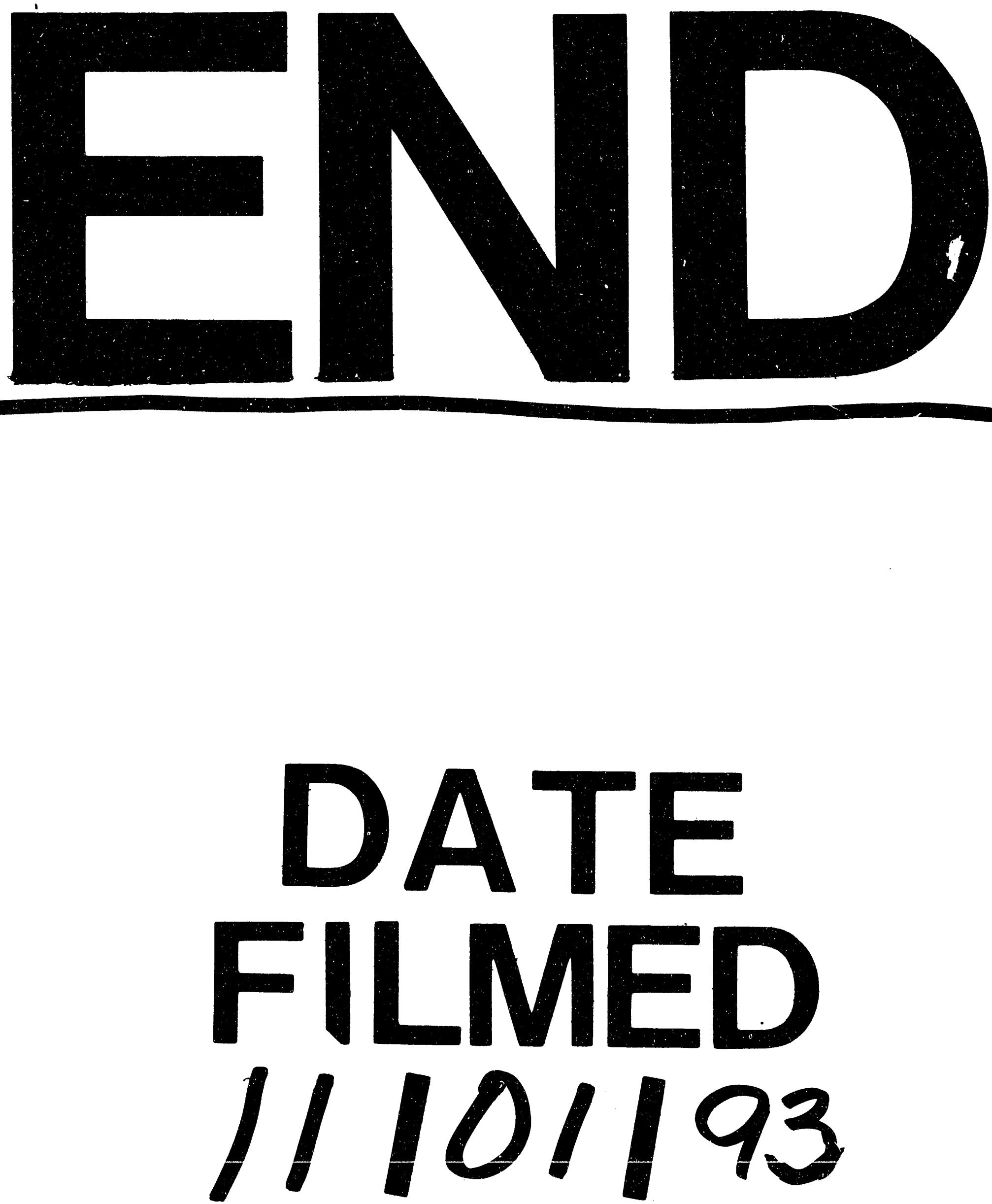
-____-

1 